\title{
Supramolecular Chemistry
}

\section{Supramolecular structure of the 1:2 complex of 1,4-dimethylpiperazine mono-betaine with squaric acid}

\section{Zofia Dega-Szafran , Andrzej Katrusiak , Anna Komasa \& Miroslaw Szafran}

To cite this article: Zofia Dega-Szafran , Andrzej Katrusiak, Anna Komasa \& Miroslaw Szafran (2013) Supramolecular structure of the 1:2 complex of 1,4-dimethylpiperazine mono-betaine with squaric acid, Supramolecular Chemistry, 25:7, 432-440, DOI: 10.1080/10610278.2013.792342

To link to this article: https://doi.org/10.1080/10610278.2013.792342

Submit your article to this journal $[\pi$

Џ Article views: 88

Q View related articles ¿

Citing articles: 9 View citing articles 5 


\title{
Supramolecular structure of the 1:2 complex of 1,4-dimethylpiperazine mono-betaine with squaric acid
}

\author{
Zofia Dega-Szafran*, Andrzej Katrusiak, Anna Komasa and Miroslaw Szafran \\ Faculty of Chemistry, Adam Mickiewicz University, Umultowska 89B, 61-614 Poznań, Poland
}

(Received 6 February 2013; final version received 26 March 2013)

\begin{abstract}
The 1:2 complex of 1,4-dimethylpiperazine mono-betaine (MBPZ) with squaric acid $\left(\mathrm{H}_{2} \mathrm{SQ}\right)$ has been characterised by singlecrystal X-ray analysis, FTIR and NMR spectroscopies, and by DFT calculations. The crystals are monoclinic, space group $P 2_{1} / c$. Two MBPZ cations and four hydrogen squarate anions $\left(\mathrm{HSQ}^{-}\right)$are linked by strong $\mathrm{O}(1)-\mathrm{H} \cdots \mathrm{O}(13)(2.525(4) \AA)$, $\mathrm{O}(14)-\mathrm{H} \cdots \mathrm{O}(21)(2.511(4) \AA)$ and $\mathrm{N}(4)-\mathrm{H} \cdots \mathrm{O}(23)(2.607(3) \AA)$ hydrogen bonds into a cyclamer $R_{6}^{6}(38)$. In turn, the cyclamers are linked into a helix $C_{4}^{4}(20)$ through two $\mathrm{O}(24)-\mathrm{H} \cdots \mathrm{O}(11)$ hydrogen bonds of $2.516(4) \AA$. The piperazinium ring has a chair conformation with $\mathrm{N}(4)-\mathrm{CH}_{3}$ and $\mathrm{N}(1)-\mathrm{CH}_{2} \mathrm{COOH}$ substituents in the equatorial positions, and $\mathrm{N}(1)-\mathrm{CH}_{3}$ in the axial position. The FTIR spectrum is consistent with the crystal data. Two models of the 1:2 complex of MBPZ with $\mathrm{H}_{2} \mathrm{SQ}$ have been optimised at the B3LYP/6-311++G(d,p) level of theory and have been used to calculate harmonic IR frequencies. One of the models (2) is dominated by electrostatic attraction between $\mathrm{NH}(4)^{+}$and $\mathrm{HSQ}^{-}$, whereas in the other (3) squaric acid interacts with a zwitterionic MBPZ through the $\mathrm{O}-\mathrm{H} \cdots \mathrm{O}$ and $\mathrm{O}-\mathrm{H} \cdots \mathrm{N}$ hydrogen bonds.
\end{abstract}

Keywords: X-ray diffraction; FTIR and NMR spectroscopy; DFT calculations; hydrogen bonds; electrostatic interactions

\section{Introduction}

Piperazine as well as 1,4-dimethylpiperazine usually shows reactions typical of aliphatic amine (1). Their two lone electron pairs can react with an electrophilic centre of different halides. $\mathrm{N}$-alkylation reactions of piperazine and 1,4-dimethylpiperazine yield symmetrically and asymmetrically substituted derivatives. The reaction pathway depends on the reaction conditions (2-7). Recently, we have studied hydrogen-bonded complexes of 1-carboxymethyl1,4-dimethylpiperazinium inner salt (1,4-dimethylpiperazine mono-betaine, MBPZ) and 1,4-dicarboxymethyl-1,4dimethylpiperazinium inner salt (1,4-dimethylpiperazine di-betaine) with $\mathrm{HCl}(7)$, p-hydroxybenzoic acid $(8,9)$, 3-iodobenzoic acid (10) and $\mathrm{L}^{-}$and meso-tartaric acids (11-13). In betaines $\left(\geq \mathrm{N}^{+}-\mathrm{CH}_{2}-\mathrm{COO}^{-}\right)$, the nitrogen atom can be surrounded by alkyls or participates in saturated five- or six-membered ring or aromatic heterocyclic ring (14).

In continuation of our previous investigation, this study focuses on the structure, hydrogen bonds, spectroscopic properties and conformation of the complex formed between MBPZ and squaric acid (3,4-dihydroxy-3cyclobutene-1,2-dione, $\mathrm{H}_{2} \mathrm{SQ}$ ) (Figure 1), supported by the Density Functional Theory (DFT) calculations. MBPZ has two different proton-acceptor centres, the carboxylate group $\left(\mathrm{p} K_{1}=1.48\right)$ and the tertiary nitrogen atom ( $\left.\mathrm{p} K_{2}=4.90\right)(7)$, whereas $\mathrm{H}_{2} \mathrm{SQ}$ is a strong acid characterised by two dissociation constants, $\mathrm{p} K_{1}=1.2-$
1.7 and $\mathrm{p} K_{2}=3.2-3.5(15-17) . \mathrm{H}_{2} \mathrm{SQ}$ by transferring one proton to a base generates a hydrogen squarate anion, $\mathrm{HSQ}^{-}$, or by transferring two protons it can generate a squarate dianion, $\mathrm{SQ}^{2-}$. The crystal complexes of $\mathrm{H}_{2} \mathrm{SQ}$ with heterocyclic amino-bases have been a subject of study of several groups; e.g. Gilli et al. (18-20), Kolev et al. (21-23), Yeşilel et al. (24-26) and Uçar et al. (24, 27, 28), and stored in the Cambridge Crystallographic Database Centre (29). Piperazine itself forms with $\mathrm{H}_{2} \mathrm{SQ}$ a 1:2 hydrated complex, where the centrosymmetric dication of piperazine is linked with $\mathrm{SQ}^{2-}$. The squarate dianions and water molecules are linked into a chain (30), whereas 1,4-dimethylpiperazine with $\mathrm{H}_{2} \mathrm{SQ}$ forms a 1:2 complex in which the squarate anions are linked into a cyclic dimer through $\mathrm{O}-\mathrm{H} \cdots \mathrm{O}$ hydrogen bond $[\mathrm{O} \cdots \mathrm{O}=2.548(3) \AA]$. The dimeric units interact with the diprotonated 1,4dimethylpiperazinium cation through $\mathrm{N}-\mathrm{H} \cdots \mathrm{O}$ and $\mathrm{C}-\mathrm{H} \cdots \mathrm{O}$ hydrogen bonds. The $\mathrm{N} \cdots \mathrm{O}$ and $\mathrm{H} \cdots \mathrm{O}$ distances in those hydrogen bonds are 2.717(3) and 1.81(5) $\AA$, respectively (31). However, in the $1: 2$ complex of 1,4-diazoniumbicyclo[2.2.2] octane (DABCO) with $\mathrm{H}_{2} \mathrm{SQ}$, DABCO as a dication and hydrogen squarate anions only form an ionic pair (32).

Because complexes of betaines with squaric acid studied so far $(33-37)$ exhibit considerable variations in their molecular structure, we have undertaken an investigation of a new complex of MBPZ with squaric acid, as an example of the interaction between a double proton-donor and a double proton-acceptor.

*Corresponding author. Email: degasz@amu.edu.pl

(C) 2013 Taylor \& Francis 
<smiles>CN1CC[N+](C)(CC(=O)[O-])CC1</smiles><smiles>O=c1c(O)c(O)c1=O</smiles>

Figure 1. Molecular structures of MBPZ inner salt and squaric acid $\left(\mathrm{H}_{2} \mathrm{SQ}\right)$.

\section{Results and discussion}

\subsection{Crystal structure}

MBPZ forms a crystalline complex with squaric acid, $\mathrm{H}_{2} \mathrm{SQ}$ (1), at the 1:2 ratio. The crystals of $\mathbf{1}$ are centrosymmetric. The labelling of atoms is shown in Figure 2. The bond lengths, bond and torsion angles are listed in Table S1 of the Supplementary Information, available online.

The piperazine ring has a chair conformation with the $\mathrm{N}(4)-\mathrm{CH}_{3}$ and $\mathrm{N}(1)^{+}-\mathrm{CH}_{2} \mathrm{COOH}$ groups in the equatorial positions and the $\mathrm{N}(1)^{+}-\mathrm{CH}_{3}$ group in the axial position. The orientation of substituent about the $\mathrm{N}(1)-\mathrm{C}(9)$ bond is staggered; the $\mathrm{C}(7)-\mathrm{N}(1)-\mathrm{C}(9)-\mathrm{C}(10)$ torsion angle is $55.7(5)^{\circ}$. The $\mathrm{N}(1)-\mathrm{C}(9)$ bond itself lies in the plane of the carboxylic group; the $\mathrm{N}(1)-\mathrm{C}(9)-\mathrm{C}(10)-\mathrm{O}(1)$ torsion angle is $-178.5(4)^{\circ}$. Each squaric acid molecule loses one proton transferred to the MBPZ molecule protonated at N(4) and $\mathrm{O}(1)$ atoms. The protonation at $\mathrm{O}(1)$ is reflected in the $\mathrm{C}(10)-\mathrm{O}(1)$ bond length of $1.302(5) \AA$, compared with the $\mathrm{C}(10)-\mathrm{O}(2)$ bond of $1.198(5) \AA$. A similar conformation has been observed in MPBZ hydrate (38) and in the 1:1 complex with p-hydroxybenzoic acid (8), whereas in the 1:2 complex of MBPZ with 3-iodobenzoic acid both $\mathrm{N}-\mathrm{CH}_{3}$ groups occupy the equatorial positions (10).
The $\mathrm{HSQ}^{-}$anions only insignificantly deviate from planarity, as illustrated by the $\mathrm{O}-\mathrm{C}-\mathrm{C}-\mathrm{O}$ torsion angles varying from $3.0(10)^{\circ}$ to $-3.7(9)^{\circ}$. The geometry of the $\mathrm{HSQ}^{-}$anions shows that both anions are non-equivalent. The $\mathrm{C}(12)-\mathrm{O}(12)$ and $\mathrm{C}(22)-\mathrm{O}(22)$ bond lengths of 1.218(5) and 1.215(6) $\AA$, respectively, indicate location of double bonds. A similar location of the $\mathrm{C}=\mathrm{C}$ and $\mathrm{C}=\mathrm{O}$ bonds in the hydrogen squarate ring has been observed in the earlier studies of squaric acid complexes $(19,23-25$, $32,35,37,39-41)$. The $\mathrm{C}-\mathrm{O}$ bond are much longer when the oxygen atom participates in the $\mathrm{OH} \cdots \mathrm{O}$ hydrogen bond (Table 1). Moreover, the $\mathrm{C}(11)-\mathrm{C}(14)-\mathrm{C}(13)$ and $\mathrm{C}(21)-\mathrm{C}(24)-\mathrm{C}(23)$ squarate ring bond angles of $93.7(3)^{\circ}$ and $92.1(4)^{\circ}$, respectively, and are more open than the other three angles in each of the squarate rings, which vary from $88.1(3)^{\circ}$ to $90.1(3)^{\circ}$ and from $87.0(9)^{\circ}$ to $90.6(3)^{\circ}$, respectively. The larger values of the $\mathrm{C}-\mathrm{C}-\mathrm{C}$ bond angles indicate that the hydroxyl groups are attached to the $\mathrm{C}(14)$ and $\mathrm{C}(24)$ carbon atoms of the $\mathrm{HSQ}^{-}$units.

The H-bonding pattern of the compound investigated is very complex. The double protonated MBPZ molecule interacts with one hydrogen squarate anion, $\mathrm{HSQ}^{-}$, through the medium strong $\mathrm{O}(1)-\mathrm{H}(1) \cdots \mathrm{O}(13)$ hydrogen bond; the $\mathrm{H}(1) \cdots \mathrm{O}(13)$ and $\mathrm{O}(1) \cdots \mathrm{O}(13)$ distances are 1.46(5) and 2.527(4) $\AA$, respectively, whereas both $\mathrm{HSQ}^{-}$ anions are joined together by the $\mathrm{O}(24)-\mathrm{H}(24) \cdots \mathrm{O}(11)$ hydrogen bond; the $\mathrm{H}(24) \cdots \mathrm{O}(11)$ and $\mathrm{O}(24) \cdots \mathrm{O}(11)$ distances are 1.45(5) and 2.516(4) $\AA$, respectively. Two protonated MBPZ cations and four squarate anions form a hydrogen-bonded cyclamer $R_{6}^{6}(38)$ around the centre of inversion (Figure 3) (42). The molecules are linked through $\mathrm{H}(1) \cdots \mathrm{O}(13), \mathrm{H}(14) \cdots \mathrm{O}(21)$ and $\mathrm{H}(4) \cdots \mathrm{O}(23)$ hydrogen bonds of 1.46(5), 1.51(4) and 1.71(4) $\AA$, respectively, whereas the $\mathrm{O}(1) \cdots \mathrm{O}(13), \mathrm{O}(14) \cdots \mathrm{O}(21)$

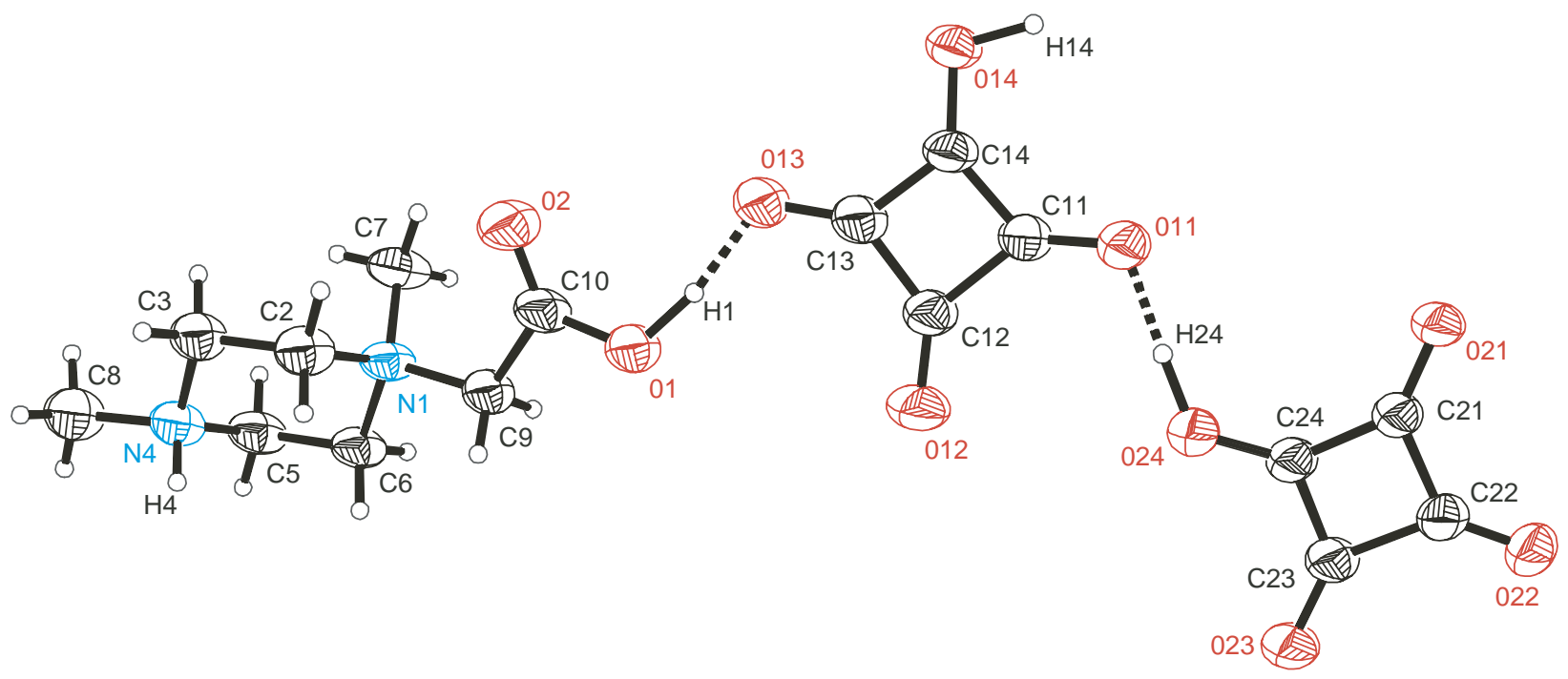

Figure 2. The symmetry-independent part of the unit cell in the 1:2 complex of MBPZ with squaric acid and atomic labels. The thermal ellipsoids have been drawn at the $50 \%$ probability level. The H-bonds have been indicated by the dashed lines. 
Table 1. Experimental and calculated by the B3LYP/6-311++G(d,p) approach geometry of hydrogen bonds and the C $-\mathrm{H} \cdots \mathrm{O}$ contacts with $\mathrm{H} \cdots \mathrm{O}$ distances shorter than $2.5 \AA$ for the $1: 2$ complex of MBPZ with squaric acid $\left(\AA,^{\circ}\right)$.

\begin{tabular}{|c|c|c|c|c|c|}
\hline & $\mathrm{D}-\mathrm{H} \cdots \mathrm{A}$ & $\mathrm{d}(\mathrm{D}-\mathrm{H})$ & $\mathrm{d}(\mathrm{H} \cdots \mathrm{A})$ & $\mathrm{d}(\mathrm{D} \cdots \mathrm{A})$ & $<(\mathrm{D}-\mathrm{H} \cdots \mathrm{A})$ \\
\hline \multicolumn{6}{|c|}{ X-ray } \\
\hline \multirow[t]{5}{*}{1} & $\mathrm{O}(1)-\mathrm{H}(1) \cdots \mathrm{O}(13)$ & $1.08(4)$ & $1.46(5)$ & $2.527(4)$ & $169(5)$ \\
\hline & $\mathrm{O}(24)-\mathrm{H}(24) \cdots \mathrm{O}(11)$ & $1.08(4)$ & $1.45(5)$ & $2.516(4)$ & $168(4)$ \\
\hline & $\mathrm{O}(14)-\mathrm{H}(14) \cdots \mathrm{O}(21)^{\mathrm{a}}$ & $1.04(4)$ & $1.51(4)$ & $2.511(4)$ & $159(4)$ \\
\hline & $\mathrm{N}(4)-\mathrm{H}(4) \cdots \mathrm{O}(23)^{\mathrm{b}}$ & $0.91(5)$ & $1.71(4)$ & $2.607(3)$ & $168(4)$ \\
\hline & $\mathrm{C}(8)-\mathrm{H}(8 \mathrm{~B}) \cdots \mathrm{O}(12)^{\mathrm{c}}$ & 0.96 & 2.447 & $3.297(4)$ & 147.4 \\
\hline \multicolumn{6}{|c|}{ B3LYP/6-311++G(d,p) } \\
\hline 2 & $\mathrm{O}(13)-\mathrm{H}(1) \cdots \mathrm{O}(1)$ & 1.045 & 1.458 & 2.489 & 167.55 \\
\hline \multirow[t]{2}{*}{3} & $\mathrm{O}(13)-\mathrm{H}(1) \cdots \mathrm{O}(1)$ & 1.052 & 1.432 & 2.478 & 172.30 \\
\hline & $\mathrm{O}(23)-\mathrm{H}(4) \cdots \mathrm{N}(4)$ & 1.010 & 1.710 & 2.687 & 161.60 \\
\hline
\end{tabular}

Note: Symmetry codes: ${ }^{\mathrm{a}}-1-x, y-0.5,1.5-z ;{ }^{\mathrm{b}} x+1,2.5-y, z-0.5 ;^{\mathrm{c}}-x, y-0.5,-z+0.5$.

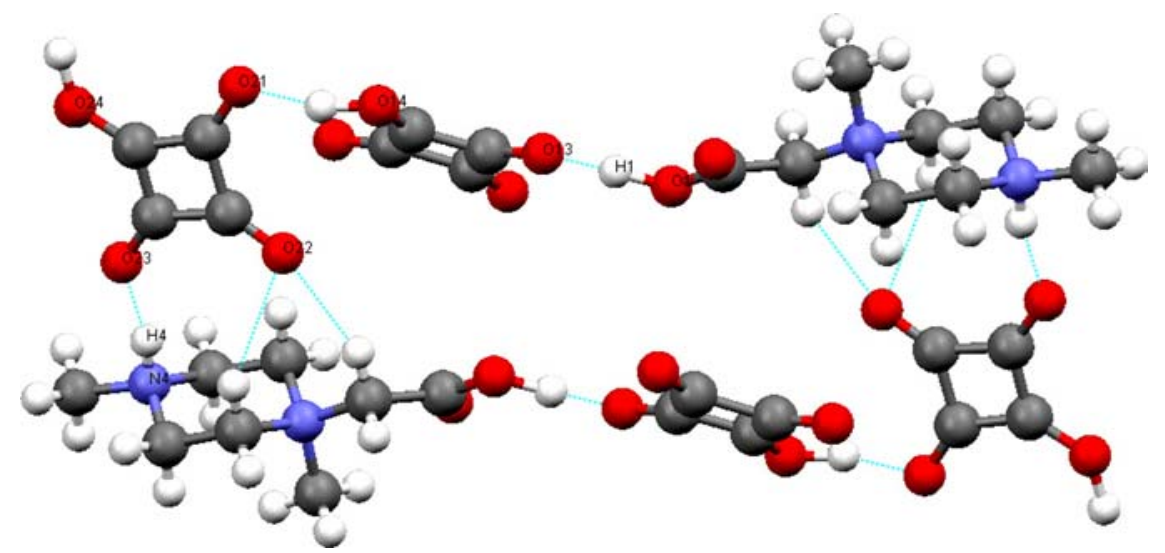

Figure 3. The hydrogen-bonded cyclamer $R_{6}^{6}(38)$ around the centre of inversion in the structure of the 1:2 complex of MBPZ with squaric acid. The $\mathrm{OH} \cdots \mathrm{O}, \mathrm{NH}^{+} \cdots \mathrm{O}$ and $\mathrm{CH} \cdots \mathrm{O}$ bonds have been indicated as dotted lines. The symmetry codes of atoms are listed in Table 1.

and $\mathrm{N}(4) \cdots \mathrm{O}(23)$ distances are $2.527(4), 2.511(4)$ and 2.607(3) A, respectively (Table 1). Two strong $\mathrm{O}(24)-\mathrm{H}(24) \cdots \mathrm{O}(11)$ hydrogen bonds $[\mathrm{H}(24)$ $\cdots \mathrm{O}(11)=1.45(5) \AA ; \quad \mathrm{O}(24) \cdots \mathrm{O}(11)=2.516(4) \AA]$ attach the $R_{6}^{6}(38)$ cyclamers to form a helix $C_{4}^{4}(20)$ about the twofold screw axis parallel to the $y$-axis (Figure 4). The autostereographic projection (43) of packing in the cell is shown in Figure 5.

\subsection{DFT calculations}

Two models of the 1:2 complex of MBPZ with $\mathrm{H}_{2} \mathrm{SQ}$ ( 2 and 3) were optimised at the B3LYP/6-311+ +G(d,p) level of theory and their structures are shown in Figure 6. The calculated bond lengths, bond and torsion angles are listed in Table S1 of the Supplementary Information, available online. The X-ray geometry of $\mathbf{1}$ was used as a starting point for the calculation of the structure of 2 . During the geometry

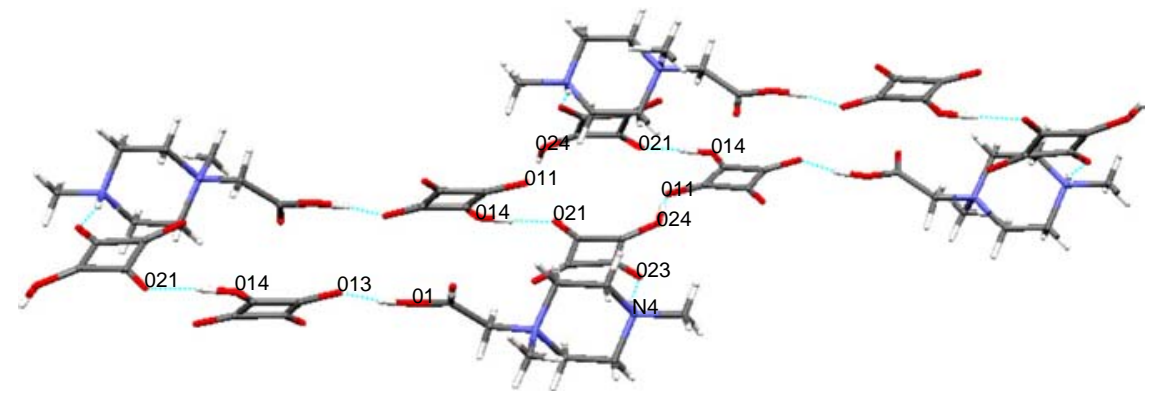

Figure 4. Two centrosymmetric $\mathrm{OH} \cdots \mathrm{O}$ and $\mathrm{NH}^{+} \ldots \mathrm{O}$ bonded cyclamers $R_{6}^{6}(38)$ in the structure of the $1: 2$ complex of MBPZ with squaric acid are $\mathrm{OH} \cdots \mathrm{O}$ bonded into a helix $C_{4}^{4}(20)$ about the twofold screw axis along the $[y]$ axis (at the centre of the drawing). The $\mathrm{OH} \cdots \mathrm{O}$ and $\mathrm{NH}^{+} \ldots \mathrm{O}$ bonds have been indicated as dotted lines. 


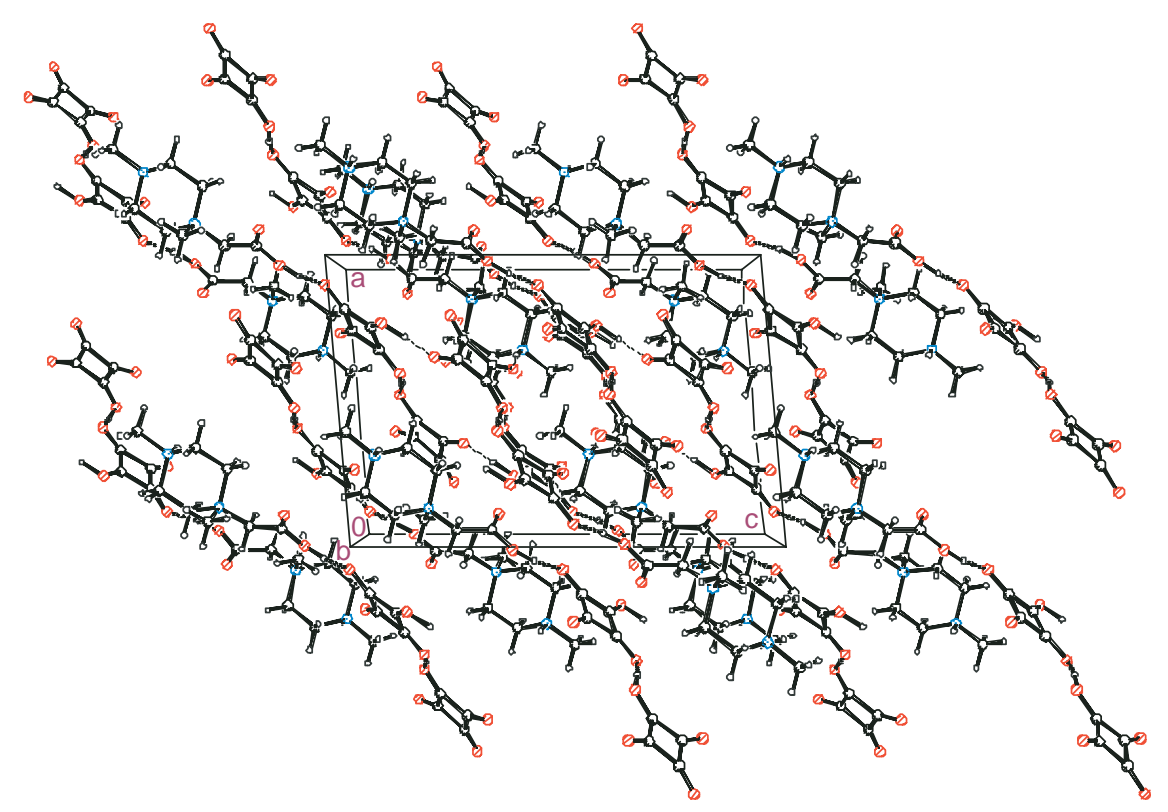

Figure 5. The crystal packing (43) in the structure of the 1:2 complex of MBPZ with squaric acid. The hydrogen bonds have been indicated by the dashed lines.

optimisation, the isolated structure becomes bent, the $\mathrm{O}(24)-\mathrm{H}(24) \cdots \mathrm{O}(11)$ hydrogen bond is broken and the electrostatic interaction between $\mathrm{N}(4)^{+}$and $\mathrm{O}(23)$ is dominant; the $\mathrm{N}(4)^{+} \ldots \mathrm{O}(23)$ distance is $3.296 \AA$, whereas the distance between $\mathrm{O}(24)$ and $\mathrm{O}(11)$ atoms increases to $9.857 \AA$. MBPZ exists in its mono-protonated form at $\mathrm{N}(4)^{+} \mathrm{H}$ cation. The carboxylate group interacts with squaric acid molecule through the $\mathrm{O}(13)-\mathrm{H}(1) \cdots \mathrm{O}(1)$ hydrogen bond; the distances $\mathrm{H}(1) \cdots \mathrm{O}(1)$ and $\mathrm{O}(13) \cdots \mathrm{O}(1)$ are 1.458 and $2.489 \AA$, respectively (Table 1). The calculated energy and dipole moments for 2 are -1483.7990738 a.u. and 12.094 D.

Model 3 consists of the MBPZ zwitterion and two squaric acids molecules (Figure 6). One molecule of squaric acid is joined to MBPZ through the $\mathrm{O}(13)-\mathrm{H}(1) \cdots \mathrm{O}(1)$ hydrogen bond, with the $\mathrm{H}(1) \cdots \mathrm{O}(1)$ and $\mathrm{O}(13) \cdots \mathrm{O}(1)$ bond lengths of 1.432 and $2.478 \AA$, respectively. The other squaric acid interacts with the tertiary nitrogen atom $\mathrm{N}(4)$ through the $\mathrm{H}(23) \cdots \mathrm{N}(4)$ hydrogen bonds of $1.710 \AA$, and the $\mathrm{O}(23) \cdots \mathrm{N}(4)$ distance of $2.687 \AA$ (Table 1). The calculated energy for $\mathbf{3}$ is -1483.8340219 a.u. and the

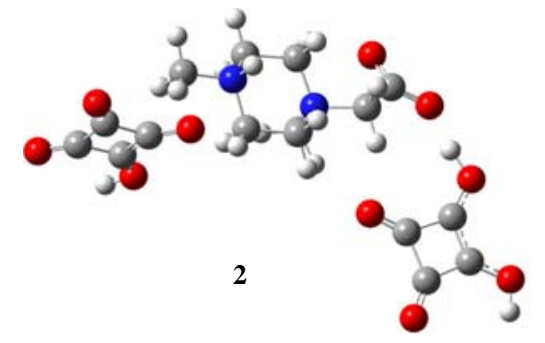

dipole moment is $14.56 \mathrm{D}$. The isolated complex of $\mathbf{3}$ is more stable than 2 by $21.93 \mathrm{kcal} \mathrm{mol}^{-1}$, which proves a significant role of the hydrogen bonds in the molecular structure of the complexes.

\subsection{Infrared spectra}

\subsubsection{The experimental IR spectrum}

The solid-state FTIR spectra of $\mathbf{1}$ and its OD-deuterated analogue are shown in Figure 7(a). According to the X-ray data, there are two medium strong $\mathrm{O}-\mathrm{H} \cdots \mathrm{O}$ hydrogen bonds of 2.527(4) and 2.516(4) $\mathrm{A}$. The $\mathrm{O}-\mathrm{H}$ stretching vibrations appear as a broad band in the range of 3000$2000 \mathrm{~cm}^{-1}$ centred at $2460 \mathrm{~cm}^{-1}$. This band shifts to the lower wave numbers in the spectrum of the deuterated sample. The $\nu$ OD band appears in the $2200-1600 \mathrm{~cm}^{-1}$ region and it overlaps the $\nu \mathrm{C}=\mathrm{O}$ bands. Two bands of low intensities at ca 3550 and $3400 \mathrm{~cm}^{-1}$ are attributed to the $\nu \mathrm{N}-\mathrm{H}$ vibrations of the group engaged in the intermolecular $\mathrm{N}-\mathrm{H} \cdots \mathrm{O}$ hydrogen bond (Table 1). An additional broad absorption is observed in the 1620-

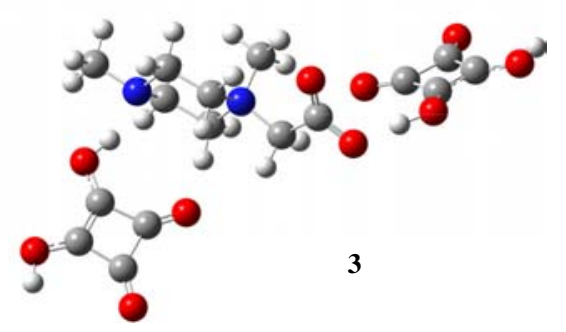

Figure 6. The structures 2 and $\mathbf{3}$ of the 1:2 complex of MBPZ with squaric acid optimised by the B3LYP/6-311 + + G(d,p) approach. 


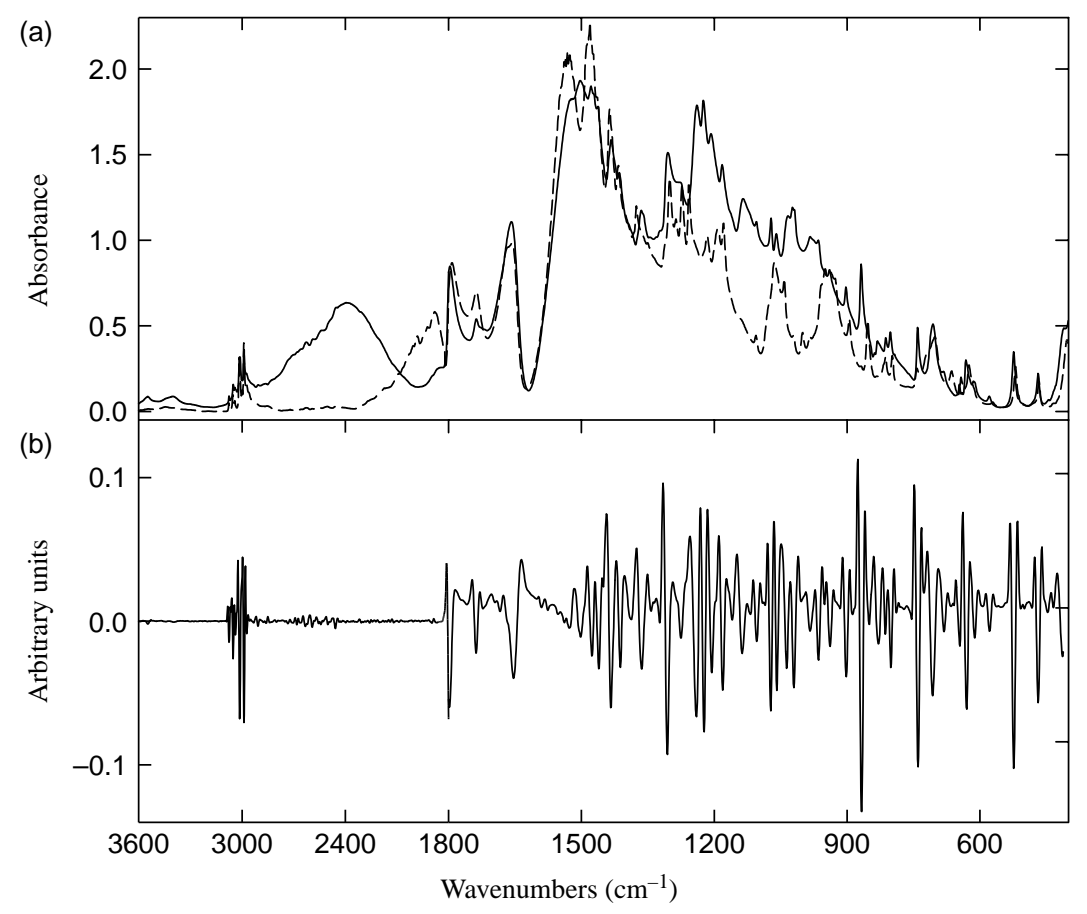

Figure 7. The experimental vibrational spectra of the complex of MBPZ with squaric acid (1): (a) FTIR spectrum and (b) its second derivative spectrum. The spectrum of the deuterated compound is drawn by a dashed line.

$500 \mathrm{~cm}^{-1}$ region with the centre of gravity at $1225 \mathrm{~cm}^{-1}$. A similar broadening of the absorption in this region is observed in the spectrum of squaric acid (44) and in the spectra of its complexes with various bases $(21,23,33$, $35,45-47)$. This broad band overlaps the $\delta \mathrm{CH}_{3}, \delta \mathrm{CH}_{2}$, $\delta \mathrm{OH}, \gamma \mathrm{CH}_{3}, \gamma \mathrm{CH}_{2}$ and $\gamma \mathrm{OH}$ vibrations. These vibrations are shown in Figure 7(b) as minima in the secondderivative spectrum, $d^{2}(48,49)$. The minima in $d^{2}$ spectrum appear at the same wave numbers as bands in the absorbance spectrum. However, the relative intensities in the $\mathrm{d}^{2}$ spectrum vary inversely to the square of the halfwidth ratio of the absorbance bands; hence, the broad bands due to $\mathrm{O}-\mathrm{H} \cdots \mathrm{O}$ modes in the FTIR spectrum are not observed in the $\mathrm{d}^{2}$ spectrum. The $\delta \mathrm{OH}$ modes appear at 1305 and ca. $1230 \mathrm{~cm}^{-1}$, whereas $\delta O D$ bands are observed at 1064 and ca. $940 \mathrm{~cm}^{-1}$. The $\gamma \mathrm{OH}$ vibration at $869 \mathrm{~cm}^{-1}$ shifts to $664 \mathrm{~cm}^{-1}$ after deuteration.

The bands at 1798,1738 and $1660 \mathrm{~cm}^{-1}$ are assigned to the $\nu \mathrm{C}=\mathrm{O}$ in $\mathrm{HSQ}^{-}$and protonated $\mathrm{MBPZ}$ molecules. In the $\mathrm{d}^{2}$ spectrum, the bands attributed to the stretching modes of $\mathrm{C}=\mathrm{O}$ appear at $1798,1757,1738,1723$ and $1653 \mathrm{~cm}^{-1}$ (Figure 7(b)).

\subsubsection{The calculated IR spectra of $\mathbf{2}$ and $\mathbf{3}$}

There are 138 frequencies in each IR spectrum of $\mathbf{2}$ and $\mathbf{3}$ calculated by the B3LYP/6-311++G(d,p) approach below $4000 \mathrm{~cm}^{-1}$. Their intensities vary from 0.1 to 3577 and from 0.1 to $3764 \mathrm{~km} / \mathrm{mol}$, respectively, for 2 and 3 . The frequencies are shown as vertical lines in Figure 8(a),(b), and the GAUSS View program (50) was used for identification of the vibration modes. Usually, the experimental and calculated spectra differ in the band frequencies and the calculated spectra appear at higher wave numbers. The discrepancy follows from two main reasons: (a) the calculations are based on harmonic frequencies and do not account for anharmonic effects and (b) the experimental spectrum is recorded for complex $\mathbf{1}$ in the solid state, whereas the computations are made for the vibrations of the isolated molecule $\mathbf{2}$ in the gas phase.

In the spectrum of 2 (Figure 8(a)), the bands at 3754 and $3744 \mathrm{~cm}^{-1}$ are attributed to the $\nu \mathrm{O}-\mathrm{H}$ vibrations of the hydroxyl group, $\mathrm{O}(14)-\mathrm{H}(14)$ and $\mathrm{O}(24)-\mathrm{H}(24)$, not engaged in the hydrogen bonds. The $\delta \mathrm{O}(14)-\mathrm{H}(14)$ and $\delta \mathrm{O}(24)-\mathrm{H}(24)$ vibrations appear at 1358 and $1363 \mathrm{~cm}^{-1}$, respectively, whereas the $\gamma \mathrm{O}(14)-\mathrm{H}(14)$ and $\gamma \mathrm{O}(24)-\mathrm{H}(24)$ modes are observed at 490 and $489 \mathrm{~cm}^{-1}$, respectively. However, the most intensive frequency at $2373 \mathrm{~cm}^{-1}$ belongs to the stretching vibration of the $\mathrm{O}(13)-\mathrm{H}(1) \cdots \mathrm{O}(1)$ mode, which confirms the presence of the short $\mathrm{O}-\mathrm{H} \cdots \mathrm{O}$ hydrogen bond of $2.489 \AA$. The deformation-in-plane and out-of-plane $\mathrm{O}(13)-\mathrm{H}(1)$ modes appear at 1437 and $1075 \mathrm{~cm}^{-1}$, respectively. The frequency at $3418 \mathrm{~cm}^{-1}$ is attributed to the free $\nu \mathrm{N}-\mathrm{H}$ vibration, whereas these at 1423 and $1058 \mathrm{~cm}^{-1}$ to the deformationin-plane and out-of-plane $\mathrm{N}-\mathrm{H}$ modes, respectively.

The $\nu_{\mathrm{as}} \mathrm{COO}$ and $\nu_{\mathrm{s}} \mathrm{COO}$ vibrations of the MPBZ unit at 1719 and $1329 \mathrm{~cm}^{-1}$ are observed. The B3LYP/6- 


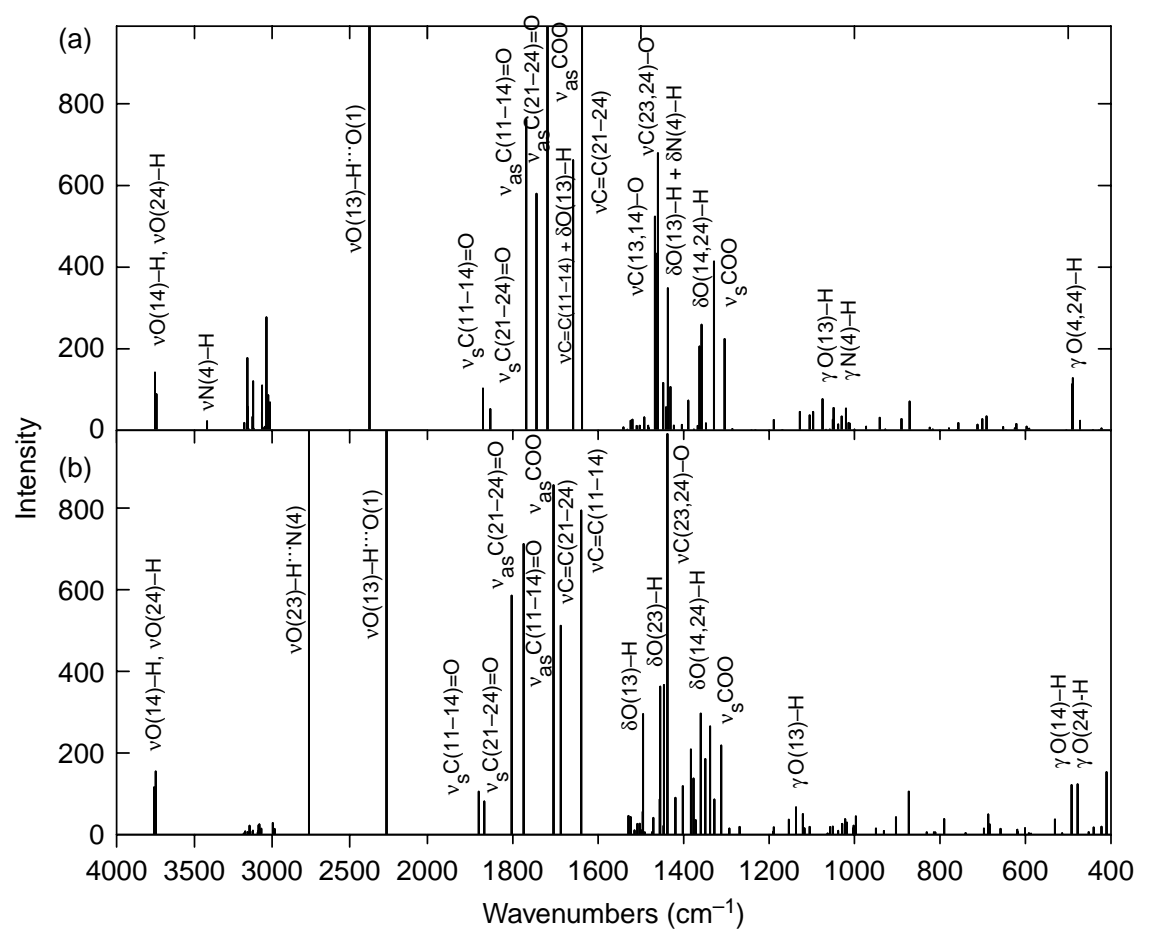

Figure 8. The infrared frequencies calculated by the B3LYP/6-311++G(d,p) approach for (a) 2 and (b) 3.

$311++\mathrm{G}(\mathrm{d}, \mathrm{p})$ method resolves the $\mathrm{C}=\mathrm{O}$ stretching modes of squarate acid and hydrogen squarate anion. The $\nu_{\mathrm{s}} \mathrm{C}(11-14)=\mathrm{O}$ and $\nu_{\mathrm{s}} \mathrm{C}(21-24)=\mathrm{O}$ vibrations appear at 1870 and $1867 \mathrm{~cm}^{-1}$, respectively, whereas $\nu_{\mathrm{as}} \mathrm{C}(11-14)=\mathrm{O}$ and $\nu_{\mathrm{as}} \mathrm{C}(21-24)=\mathrm{O}$ vibrations appear at 1769 and $1745 \mathrm{~cm}^{-1}$ (Figure 8(a)).

The calculated IR spectrum of $\mathbf{3}$ is shown in Figure 8 (b). The free vibrations of $\mathrm{O}(14)-\mathrm{H}(14)$ and $\mathrm{O}(24)-\mathrm{H}(24)$ bands appear at 3758 and $3750 \mathrm{~cm}^{-1}$. However, the stretching vibration of $\mathrm{O}(13)-\mathrm{H}(1) \cdots \mathrm{O}(1)$ at $2263 \mathrm{~cm}^{-1}$ is shifted to the lower wave numbers in comparison with this band in the spectrum of $\mathbf{2}$, which is caused by a slight shortening of the $\mathrm{O}(13)-\mathrm{H}(1) \cdots \mathrm{O}(1)$ hydrogen bond of $2.478 \AA$ (Table 1 ). The band at $2763 \mathrm{~cm}^{-1}$ is assigned to the stretching vibration of the $\mathrm{O}(23)-\mathrm{H}(4) \cdots \mathrm{N}(4)$ bond involved in the hydrogen bond, which evidences the different interactions of the molecules in the optimised structures 2 and 3 . The $\delta \mathrm{O}(13)-\mathrm{H}$, $\delta \mathrm{O}(23)-\mathrm{H}, \delta \mathrm{O}(14)-\mathrm{H}$ and $\delta \mathrm{O}(24)-\mathrm{H}$ modes appear at $1495,1456,1343$ and $1360 \mathrm{~cm}^{-1}$, respectively, whereas $\gamma \mathrm{O}(13)-\mathrm{H}, \gamma \mathrm{O}(14)-\mathrm{H}$ and $\gamma \mathrm{O}(24)-\mathrm{H}$ modes appear at 1154,478 and $492 \mathrm{~cm}^{-1}$, respectively. Similarly as in the spectrum of 2 , the $\nu_{\mathrm{s}} \mathrm{C}(11-14)=\mathrm{O}$ and $\nu_{\mathrm{s}} \mathrm{C}(21-24)=\mathrm{O}$ vibrations appear at 1880 and $1853 \mathrm{~cm}^{-1}$, respectively, whereas the $v_{\mathrm{as}} \mathrm{C}(11-14)=\mathrm{O}$ and $v_{\mathrm{as}} \mathrm{C}(21-24)=\mathrm{O}$ vibrations appear at 1775 and $1803 \mathrm{~cm}^{-1}$, respectively. The spectral features of the squarate units are similar to those observed earlier $(21,23,33,35,44-47,51)$.

The calculated IR spectrum of $\mathbf{3}$ reproduced the experimental spectrum much better than that of $\mathbf{2}$, because both $\mathrm{O}-\mathrm{H} \cdots \mathrm{N}$ and $\mathrm{O}-\mathrm{H} \cdots \mathrm{O}$ intermolecular interactions are observed in the optimised structure of $\mathbf{3}$.

\subsection{NMR spectra}

The proton and carbon-13 chemical shifts for the complex of MBPZ with $\mathrm{H}_{2} \mathrm{SQ}$ are listed in Table 2 and the spectra are shown in Figure 9. The assignments are based on 2D

Table 2. The ${ }^{1} \mathrm{H}$ and ${ }^{13} \mathrm{C}$ chemical shifts for the complex of MBPZ with squaric acid.

\begin{tabular}{lrr}
\hline Atom & $\mathrm{D}_{2} \mathrm{O}^{\mathrm{b}}$ & DMSO- ${ }_{6}^{\mathrm{c}}$ \\
${ }^{\mathrm{1}} \mathrm{H}$ & 4.14 & \\
$\mathrm{H}(2,6 \mathrm{eq})$ & 3.87 & 3.87 \\
$\mathrm{H}(2,6 \mathrm{ax})$ & 3.87 & 3.82 \\
$\mathrm{H}(3,5)$ & 3.53 & 3.42 \\
$\mathrm{C}(7) \mathrm{H}_{3}$ & 3.09 & 3.37 \\
$\mathrm{C}(8) \mathrm{H}_{3}$ & 4.39 & 2.73 \\
$\mathrm{C}(9) \mathrm{H}_{2}$ & & 4.48 \\
${ }^{13} \mathrm{C}$ & 60.11 & \\
$\mathrm{C}(2,6)$ & 50.09 & 57.76 \\
$\mathrm{C}(3,5)$ & 48.56 & 46.45 \\
$\mathrm{C}(7)$ & 45.66 & 42.38 \\
$\mathrm{C}(8)$ & 68.69 & 61.18 \\
$\mathrm{C}(9)$ & 169.79 & 166.05 \\
$\mathrm{C}(10)$ & 198.69 & 194.67 \\
$\mathrm{C}(11-14)$ & & \\
\hline
\end{tabular}

${ }^{\mathrm{a}}$ For numbering of atoms see Figure 1.

${ }^{\mathrm{b}}$ At $400 \mathrm{MHz}$.

${ }^{\mathrm{c}}$ At $600 \mathrm{MHz}$. 
(a)

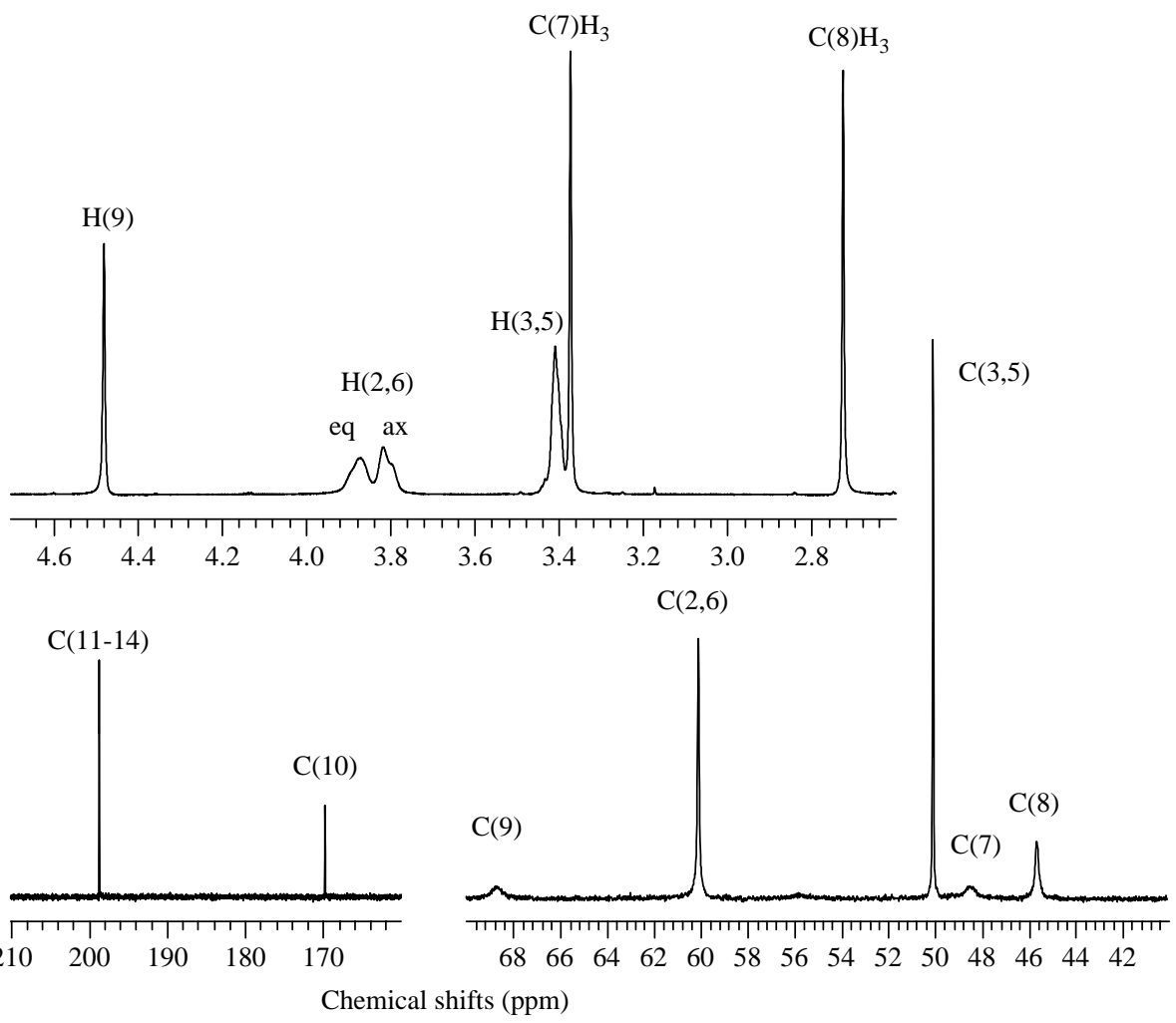

Figure 9. The NMR spectra of the complex of MBPZ with squaric acid; ${ }^{1} \mathrm{H}(\mathrm{a})$ in DMSO- $d_{6}$ and ${ }^{13} \mathrm{C}(\mathrm{b})$ in $\mathrm{D}_{2} \mathrm{O}$.

measurements of ${ }^{1} \mathrm{H}-{ }^{1} \mathrm{H}$ (COSY), ${ }^{1} \mathrm{H}-{ }^{13} \mathrm{C}$ (HETCOR) and heteronuclear multiple-bond connectivity (HMBC) (52). The NMR spectra were measured in $\mathrm{D}_{2} \mathrm{O}$ and DMSO- $d_{6}$.

The ${ }^{1} \mathrm{H}$ NMR spectrum in DMSO- $d_{6}$ (Figure 9(a)) of the complex investigated is very similar to that observed for the complex of MBPZ with 3-iodobenzoic acid (10), and it is characterised by three sharp and intensive singlets attributed to the resonance signals of $\mathrm{C}(8) \mathrm{H}_{3}, \mathrm{C}(7) \mathrm{H}_{3}$ methyl groups and $\mathrm{C}(9) \mathrm{H}_{2}$ methylene protons at 2.73, 3.37 and $4.48 \mathrm{ppm}$, respectively. Two broad low-intensity resonance signals at 3.87 and $3.82 \mathrm{ppm}$ are assigned to the equatorial (eq) and axial (ax) methylene ring protons at $\mathrm{C}(2,6)$, respectively (Figure 9(a)). The resonance signal of the axial ring protons at the carbon $(2,6)$ attached to the quaternary nitrogen atom in the spectra of six-membered azacycles is usually more shielded in comparison with those at the equatorial positions (53). In the ${ }^{1} \mathrm{H}$ NMR spectrum in DMSO- $d_{6}$, the signals of the equatorial and axial protons are better separated, whereas in the spectrum in $\mathrm{D}_{2} \mathrm{O}$, the resonance signal of $\mathrm{H}(2,6 \mathrm{ax})$ protons overlaps the signal of the $H(3,5)$ protons (Table 2). The signals of the equatorial and axial protons at $C(3,5)$ merge into a multiplet at 3.42 and $3.87 \mathrm{ppm}$ in the spectra measured in DMSO- $d_{6}$ and $\mathrm{D}_{2} \mathrm{O}$ solutions, respectively. The protonation of the $\mathrm{N}(4)$ atom causes downfield shifts of the signals of $\mathrm{C}(8) \mathrm{H}_{3}$ and $\mathrm{C}(3,5) \mathrm{H}_{2}$ protons in comparison with those in the spectrum of MBPZ-3-iodobenzoic acid complex (10).

The ${ }^{13} \mathrm{C}$ NMR spectrum in $\mathrm{D}_{2} \mathrm{O}$, shown in Figure 9(b), consists of two sharp signals at 60.11 and $50.09 \mathrm{ppm}$ assigned to the piperazine ring carbon atoms $\mathrm{C}(2,6)$ and $\mathrm{C}(3,5)$, respectively. The less intense signal at $45.66 \mathrm{ppm}$ is attributed to the $\mathrm{C}(8)$ methyl carbon atom at $\mathrm{N}(4)^{+}$. Similarly, as in the carbon-13 spectra of 1,4-dimethylpiperazine, tetramethylpiperazinium salts (54), MBPZ, and its complexes with acids $(8-10)$, signals attributed to the methyl, $\mathrm{C}(7) \mathrm{H}_{3}$, and carboxymethylene, $\mathrm{C}(9) \mathrm{H}_{2} \mathrm{COOH}$, groups are broad and of very low intensity. This broadening can be caused by the quadrupole effect of the charged $\mathrm{N}(1)^{+}$atom and the conformational changes around the positively charged nitrogen atom $(54,55)$. The resonance signal of $\mathrm{C}(10)$ of the $\mathrm{COO}$ group appears at 169.79 and $166.05 \mathrm{ppm}$ in the spectra measured in $\mathrm{D}_{2} \mathrm{O}$ and DMSO- $d_{6}$, respectively.

The $\mathrm{HSQ}^{-}$unit in the ${ }^{13} \mathrm{C}$ NMR spectrum is characterised by only one average resonance signal of $\mathrm{C}(11)-\mathrm{C}(14)$ and $\mathrm{C}(21)-\mathrm{C}(24)$ carbon atoms at $194.67 \mathrm{ppm}$ in DMSO- $d_{6}$ solution and at $198.69 \mathrm{ppm}$ in $\mathrm{D}_{2} \mathrm{O}$ solution. The later value of the chemical shifts of the cyclobutene ring carbon atoms confirms the presence of the $\mathrm{HSQ}^{-}$anion in the complex (36). 


\section{Conclusions}

In the 1:2 complex of MBPZ with squaric acid $\left(\mathrm{H}_{2} \mathrm{SQ}\right)$, the MBPZ dication interacts with the dimer of hydrogen squarate anion, $\left(\mathrm{HSQ}^{-}\right)_{2}$, through the medium strong $\mathrm{O}-\mathrm{H} \cdots \mathrm{O}$ hydrogen bonds of 2.527(4) and 2.516(4) A. Two such complexes form a cyclamer $R_{6}^{6}(38)$, which is further linked to a helix $C_{4}^{4}(20)$. The structures optimised by the B3LYP/6-311++G(d,p) method agree with different protonation side, electrostatic interactions and spectroscopies properties. In the ${ }^{1} \mathrm{H}$ NMR spectrum in DMSO- $d_{6}$, the resonance signals of piperazine ring protons are better resolved than in $\mathrm{D}_{2} \mathrm{O}$, whereas in the ${ }^{13} \mathrm{C}$ NMR spectrum resonance signals of methyl and methylene carbons are broad and of low intensities.

\section{Experimental section}

\subsection{General}

FTIR spectra were measured in Nujol and Fluorolube suspensions between KBr plates using a Bruker IFS 66v/S. The NMR spectra were recorded using a Varian VNMRS400 spectrometer and a Bruker Advance DRX spectrometer at 599.93 and $150.85 \mathrm{MHz}$ for ${ }^{1} \mathrm{H}$ and ${ }^{13} \mathrm{C}$, respectively. The spectra were measured in $\mathrm{D}_{2} \mathrm{O}$ relative to an internal standard of 3-(trimethylsilyl)propionic- $\mathrm{d}_{4}$ acid sodium salt and in DMSO- $d_{6}$ relative to tetramethylsilane.

\subsection{Synthesis}

MBPZ was synthesised according to the method described in Ref. (7). The complex of MBPZ with squaric acid $\left(\mathrm{H}_{2} \mathrm{SQ}\right)$, (1), was prepared by mixing $0.54 \mathrm{~g}$ of $\mathrm{MBPZ}$ dissolved in $2 \mathrm{ml}$ of methanol with $0.69 \mathrm{~g}$ of $\mathrm{H}_{2} \mathrm{SQ}$ dissolved in $2 \mathrm{ml}$ of water. The precipitate was filtered off and the residue was recrystallised from a mixture of methanol-water (1:1); m.p. $238-239^{\circ} \mathrm{C}$. Elemental analysis calculated for $\mathrm{C}_{16} \mathrm{H}_{20} \mathrm{~N}_{2} \mathrm{O}_{10}: \% \mathrm{C}, 48.00 ; \% \mathrm{H}$, 5.04; \% N, 7.00; found: $\% \mathrm{C}, 48.03 ; \% \mathrm{H}, 5.20 ; \% \mathrm{~N}, 7.12$. A deuterated sample was prepared by a threefold dissolution in $\mathrm{D}_{2} \mathrm{O}$, with subsequent removal of the solvent under reduced pressure, and finally recrystallised from $\mathrm{CH}_{3} \mathrm{OD}$.

\subsection{Crystallography}

Recrystallised from $\mathrm{CH}_{3} \mathrm{OH}-\mathrm{H}_{2} \mathrm{O}$ (1:1). Crystal data: $\mathrm{C}_{16} \mathrm{H}_{20} \mathrm{~N}_{2} \mathrm{O}_{10} ; M=400.34$; crystal system: monoclinic; space group: $P 2{ }_{1} / c ; a=11.0465(7) \AA, b=9.6813(3) \AA$, $c=16.4490(7) \AA, \quad \beta=95.043(4)^{\circ}, \quad V=1752.32(15) \AA^{3}$; $Z=4 ; \quad D_{\mathrm{c}}=1.517 \mathrm{~g} / \mathrm{cm}^{3} ; R_{\mathrm{int}}=0.0444, R\left[I>2 \sigma_{I}\right]=$ $0.0392, w R\left[I>2 \sigma_{I}\right]=0.0571$ for 10,455 unique reflections. The crystal structure of the complex of MBPZ with $\mathrm{H}_{2} \mathrm{SQ}$ (1) was determined by X-ray diffraction, measured with a KUMA KM-4 CCD diffractometer $(56,57)$. The structure was solved by direct methods using SHELXS-97 and refined on $F^{2}$ by full-matrix least-squares with SHELXL-97 (58). The crystal data, details of data collection and structure refinement are given in Table S1 of the Supplementary Information, available online and the final atomic coordinates are in Table S1 of the Supplementary Information, available online. The complete set of structural parameters in CIF format is available as an Electronic Supplementary Publication from the Cambridge Crystallographic Database Centre (CCDC 922913). For further details, see www.ccdc.cam.ac.uk/cgibin/catreq-cgi.

\subsection{DFT calculations}

The DFT calculations were carried out with the GAUSSIAN 09 program package (59). The calculations employed the B3LYP exchange-correlation functional, which combines the hybrid exchange functional of Becke $(60,61)$ with the gradient-correlation functional of Lee et al. (62) and the split-valence polarised 6-311++G(d,p) basis set (63). The calculated IR frequencies were positive and confirmed that the optimised structures were in the states of minimum energies.

\section{Supplementary information}

Supplementary data (Tables S1-S3) associated with this article can be found in online version at http://dx.doi.org/ 10.1080/10610278.2013.792342

\section{Acknowledgements}

The computation has been performed in Poznań Supercomputing and Networking Centre and in PL-Grid Infrastructure.

\section{References}

(1) Katritzky, A.R. Handbook of Heterocyclic Chemistry; Pergamon Press: Oxford, 1985.

(2) Moore, T.S.; Boyle, M.; Thorn, V.M. J. Chem. Soc. 1927, 39-50.

(3) Adelson, D.E.; Pollard, C.B. J. Am. Chem. Soc. 1935, 57, 1280-1281.

(4) Smith, D.R.; Maienthal, M.; Eifert, R.L. J. Am. Chem. Soc. 1951, 73, 2964-2965.

(5) Baltzly, R. J. Am. Chem. Soc. 1954, 76, 1164-1166.

(6) Ziegler, E.; Wittmann, H. Monatsh. Chem. 1985, 116, $821-829$.

(7) Dega-Szafran, Z.; Jaskólski, M.; Kurzyca, I.; Barczyński, P.; Szafran, M. J. Mol. Struct. 2002, 614, 23-32.

(8) Dega-Szafran, Z.; Katrusiak, A.; Szafran, M. J. Mol. Struct. 2006, 785, 160-166.

(9) Dega-Szafran, Z.; Katrusiak, A.; Szafran, M. J. Mol. Struct. 2006, 797, 82-91.

(10) Dega-Szafran, Z.; Katrusiak, A.; Szafran, M. J. Mol. Struct. 2008, 875, 577-586. 
(11) Dega-Szafran, Z.; Katrusiak, A.; Szafran, M. J. Mol. Struct. 2008, 891, 258-265.

(12) Dega-Szafran, Z.; Katrusiak, A.; Szafran, M. J. Mol. Struct. 2008, 892, 353-359.

(13) Dega-Szafran, Z.; Katrusiak, A.; Szafran, M. J. Mol. Struct. 2009, 920, 202-207.

(14) Domingo, X. Betaines. In Amphoteric Surfactants; Lomax, E.G., Ed.; Marcel Dekker Inc.: New York, 1996; Vol. 59, pp $75-190$.

(15) Cohen, S.; Lacher, J.R.; Park, J.D. J. Am. Chem. Soc. 1959, 81,3480 .

(16) MacDonald, D.J. J. Org. Chem. 1968, 33, 4559-4560.

(17) Ireland, D.T.; Walton, H.F. J. Phys. Chem. 1967, 71, $751-754$.

(18) Gilli, G.; Gilli, P. The Nature of the Hydrogen Bond, Outline of a Comprehensive Hydrogen Bond Theory; Oxford University Press: Oxford, 2009; pp 251-253.

(19) Gilli, G.; Bertolasi, V.; Gilli, P.; Ferretti, V. Acta Crystallogr. 2001, B57, 859-865.

(20) Bertolasi, V.; Gilli, P.; Ferretti, V.; Gilli, G. Acta Crystallogr. 2001, B57, 591-598.

(21) Koleva, B.B.; Kolev, T.; Seidel, R.W.; Mayer-Figge, H.; Spiteller, M.; Sheldrick, W.S. J. Phys. Chem. 2008, A112, 2899-2905.

(22) Koleva, B.B.; Kolev, T.; Seidel, R.W.; Spiteller, M.; Mayer-Figge, H.; Sheldrick, W.S. J. Phys. Chem 2009, A 113, 3088-3095, and references cited therein.

(23) Kolev, T.; Mayer-Figge, H.; Seidel, R.W.; Sheldrick, W.S.; Spiteller; Koleva, B.B. J. Mol. Struct. 2009, 919, 246-254.

(24) Uçar, I.; Bulut, A.; Yeşilel, O.Z.; Büyükgüngör, O. Acta Crystallogr. 2004, C60, o585-o588.

(25) Bulut, A.; Yeşilel, O.Z.; Dege, N.; Icbudak, H.; Olmez, H.; Buyukgungor, O. Acta Crystallogr. 2003, C59, o727-o729.

(26) Yeşilel, O.Z.; Odabaşoğlu, M.; Büyükgüngör, O. J. Mol. Struct. 2008, 874, 151-158.

(27) Uçar, I.; Bulut, A.; Büyükgüngör, O. Acta Crystallogr. 2007, E63, o3377.

(28) Köroglu, A.; Bulut, A.; Uçar, I.; Nichol, G.S.; Harrington, R.W.; Clegg, W. Acta Crystallogr. 2005, C61, o678-o680.

(29) The Cambridge Crystallographic Database Centre, http:// www.ccdc.cam.ac.uk/.

(30) MacLean, E.J.; Wheatley, P.S.; Ferguson, G.; Glidewell, Ch.; Lough, A. J. Acta Crystallogr. 1999, C55, 1896-1899.

(31) Mathew, S.; Paul, G.; Shivasankar, K.; Choudhury, A.; Rao, C.N.R. J. Mol. Struct. 2002, 641, 263-279.

(32) Barczyński, P.; Dega-Szafran, Z.; Katrusiak, A.; Szafran, M. J. Mol. Struct. 2011, 998, 240-245.

(33) Barczyński, P.; Dega-Szafran, Z.; Katrusiak, A.; Szafran, M. J. Mol. Struct. 2012, 1013, 95-101.

(34) Dega-Szafran, Z.; Dutkiewicz, G.; Kosturkiewicz, Z.; Szafran, M. J. Mol. Struct. 2012, 1015, 86-93.

(35) Barczyński, P.; Dega-Szafran, Z.; Katrusiak, A.; Szafran, M. J. Mol. Struct. 2012, 1018, 28-34.

(36) Dega-Szafran, Z.; Dutkiewicz, G.; Kosturkiewicz, Z. J. Mol. Struct. 2012, 1029, 28-34.

(37) Dega-Szafran, Z.; Katrusiak, A.; Szafran, M. J. Mol. Struct. 2012, 1030, 184-190.

(38) Dega-Szafran, Z.; Katrusiak, A.; Szafran, M. J. Mol. Struct. 2008, 880, 69-76.

(39) Nowicka-Scheibe, J.; Grech, E.; Sawka-Dobrowolska, W.; Bator, G.; Sobczyk, L. Polish J. Chem. 2007, 81, 643-652.

(40) Angelova, O.; Petrova, R.; Radomirska, V.; Kolev, T. Acta Crystallogr. 1996, C52, 2218-2220.
(41) MacLean, E.J.; Wheatley, P.S.; Ferguson, G.; Glidewell, Ch. Acta Crystallogr. 1999, C55, 1892-1896.

(42) Etter, M.C.; MacDonald, J.C.; Bernstein, J. Acta Crystallogr. 1990, B46, 256-262.

(43) Katrusiak, A. J. Mol. Graph. Model. 2001, 19, 363-367.

(44) Baglin, F.G.; Rose, C.B. Spectrochim. Acta 1970, 26A, 2293-2304.

(45) Koleva, B.; Kolev, T.; Seidel, R.W.; Tsanev, T.; MayerFigge, H.; Spiteller, M.; Sheldrick, W.S. Spectrochim. Acta 2008, 71A, 695-702.

(46) Kolev, T.; Seidel, R.W.; Koleva, B.B.; Mayer-Figge, H.; Spiteller, M.; Sheldrick, W.S. J. Mol. Struct. 2009, 931, 45-49.

(47) Koleva, B.; Seidel, R.W.; Kolev, T.; Zareva, S.; MayerFigge, H.; Oppel, I.M.; Sheldrick, W.S. J. Mol. Struct. 2009, 921, 163-171.

(48) Maddams, W.F.; Southon, M.J. Spectrochim. Acta 1992, $38 A, 459-466$.

(49) Talsky, G. Derivative Spectrophotometry; VCH: Weinheim, 1994.

(50) Frisch, A.E.; Dennington, R.D.; Keith, T.A.; Neilsen, A.B.; Holder, A.J. GaussView, 3.0.9; Gaussian, Inc.: Pittsburgh, PA, 2003.

(51) Kolev, T.M.; Stamboliyska, B.A.; Yancheva, D.Y.; Enchev, V. J. Mol. Struct. 2004, 691, 241-248.

(52) Simpson, J.H. Organic Structure Determination Using 2-D NMR Spectroscopy; Academic Press, Elsevier: Amsterdam, 2008.

(53) Lambert, J.B.; Keske, R.G.; Carhart, R.E.; Jovanovich, A.P. J. Am. Chem. Soc. 1967, 89, 3761-3767.

(54) Coddington, J.M.; Taylor, M.J. Spectrochim. Acta 1990, 46A, 1487-1497.

(55) Taylor, M.J.; Calvert, D.; Hobbis, C.M. Magn. Reson. Chem. 1988, 26, 619-620.

(56) KUMA KM4 CCD Software, version 161; Kuma Diffraction: Wroclaw, Poland, 1999.

(57) CrysAlis 162; Kuma Diffraction: Wroclaw, Poland, 1999.

(58) Sheldrick, G.M. Acta Crystallogr. 2008, A64, 112-122.

(59) Frisch, M.J.; Trucks, G.W.; Schlegel, H.B.; Scuseria, G.E.; Robb, M.A.; Cheeseman, J.R.; Scalmani, G.; Barone, V.; Mennucci, B.; Petersson, G.A.; Nakatsuji, H.; Caricato, M.; Li, X.; Hratchian, H.P.; Izmaylov, A.F.; Bloino, J.; Zheng, G.; Sonnenberg, J.L.; Hada, M.; Ehara, M.; Toyota, K.; Fukuda, R.; Hasegawa, J.; Ishida, M.; Nakajima, T.; Honda, Y.; Kitao, O.; Nakai, H.; Vreven, T.; Montgomery, J.A. Jr.; Peralta, J.E.; Ogliaro, F.; Bearpark, M.; Heyd, J.J.; Brothers, E.; Kudin, K.N.; Staroverov, V.N.; Keith, T.; Kobayashi, R.; Normand, J.; Raghavachari, K.; Rendell, A.; Burant, J.C.; Iyengar, S.S.; Tomasi, J.; Cossi, M.; Rega, N.; Millam, J.M.; Klene, M.; Knox, J.E.; Cross, J.B.; Bakken, V.; Adamo, C.; Jaramillo, J.; Gomperts, R.; Stratmann, R.E.; Yazyev, O.; Austin, A.J.; Cammi, R.; Pomelli, C.; Ochterski, J. W.R.; Martin, L.; Morokuma, K.; Zakrzewski, V.G.; Voth, G.A.; Salvador, P.; Dannenberg, J.J.; Dapprich, S.; Daniels, A.D.; Farkas, O.; Foresman, J. B.; Ortiz, J.V.; Cioslowski, J.; Fox, D.J. Gaussian 09, Revision C.01; Gaussian, Inc.: Wallingford, CT, 2010.

(60) Becke, A.D. J. Chem. Phys. 1993, 98, 5648-5652.

(61) Becke, A.D. J. Chem. Phys. 1997, 107, 8554-8580.

(62) Lee, C.; Yang, C.W.; Parr, G.R. Phys. Rev. 1988, B37, 785-789.

(63) Hehre, W.J.; Random, L.; Schleyer, P.V.R.; Pople, J.A. Ab Initio Molecular Orbital Theory; Wiley: New York, 1986. 